\title{
TWO BASE GENERATED STRUCTURES FOR DITRANSITIVES IN EUROPEAN PORTUGUESE ${ }^{1}$
}

\author{
ANA MARIA BRITO
}

\section{RESUMO}

0 artigo retoma um tema muito discutido na bibliografia sintática, a questão de saber se o Português Europeu tem alternância dativa. Será proposto que nesta língua há duas estruturas sintáticas basicamente engendradas para as construções ditransitivas e, deste modo, o Português Europeu terá alternância dativa, mas num sentido muito diferente do que tem o Inglês e outras línguas germânicas. Será proposto que não se justifica o nó aplicativo nesta língua e que a preposição é, nas duas construções, o mesmo tipo de preposição, essencialmente um marcador de caso dativo. As razões para a proposta são certos factos de ordem de palavras, anteposição, ligação e escopo.

\section{[1] INTRODUCTION}

Several Germanic languages have dative alternation, because they exhibit two synonymous constructions: a prepositional construction with to (1-a) in the order Direct Object (DO) + Indirect Object (IO) and the Double Object Construction (DOC) (1-b), characterized by the existence of two NPs with certain order restrictions: only the pattern $\mathrm{V}+$ goal / beneficiary + theme is accepted:

(1) a. John gave a book to Mary.

b. John gave Mary a book.

As Romance languages have special prepositions for the expression of the dative $(a, \grave{a})$, it is classically assumed (see, among others, Kayne (1984)) that these languages have no DOC. Of course there are many languages without prepositions. Among them Bantu languages deserve a special attention, because they have applicative constructions, where verbs may add or "apply" a new argument to the verb root with the help of a special infix, an applicative morpheme. Connected to this view is the idea, shared by several linguists, that there are no true ditransitive verbs, but only verbs that select an internal argument and that may add a new participant, the so called IO. These reasons justified the proposal, made in different ways by Baker (1988), Marantz (1993) and Pylkkänen (2002), of a related analysis of the DOC and of applicative constructions.

[1] This paper is a short and English version of Brito (2014). 
It is in this direction that the analysis by Torres Morais (2006) and Torres Morais \& Lima-Salles (2010) about EP is situated: the idea is that in EP the so called IO is found in two configurations: one where the IO is projected in the specifier position of a low applicative head, as a dative NP, and another one involving a lexical / true preposition, where the IO is the complement of the preposition. This proposal is mainly based on two reasons: (i) the two available IO constructions would not be synonymous; (ii) the preposition a would have two values in EP: as dative marker and as true preposition.

The main goal of this text is to analyse some syntactic issues of ditransitive constructions in European Portuguese. ${ }^{2}$ I will argue in favour of two different base-generated syntactic constructions; this proposal is not based neither on the existence of two distinct values of a nor on semantic differences, but on word order, binding, scope, fronting and ellipsis phenomena, some of them already studied by Costa (2009) and Brito $(2010,2014)$. Therefore, the proposal approaches other previous analyses, but discusses the existence in EP of the dative alternation in the English sense, the existence of two $a$ different dative prepositions and the necessity of an applicative head.

The text is organised in the following way: in section [2], I present some data about the IO / datives in EP; in section [3], I refer some classical approaches about IO / datives in Generative Syntax; in section [4], I comment Torres Morais \& Lima Salles analysis of EP ditransitive constructions; in section [5], I will defend that in EP there are two base-generated ditransitive constructions; and in section [6], I will present the main conclusions of this study.

[2] EP: SOME DATA ON DITRANSITIVE CONSTRUCTIONS

European Portuguese (EP) expresses the IO either by the preposition a followed by a NP or by dative case expressed by the personal pronouns me, te, lhe, nos, vos, lhes; the examples in (2)-(4) illustrate these possibilities: ${ }^{3}$

(2) VNP a NP (V DO IO)

A Maria deu um livro ao João.

the Mary gave a book to.the John

'Mary gave a book to John'

[2] About argument and non-argument datives in European Portuguese see, among others, Vilela (1992), Brito (2009), Miguel et al. (2011), Gonçalves \& Raposo (2013), specially pp. 1173-1181.

[3] I will use the following category symbols: NP (Noun Phrase), VP (Verb Phrase), PP (Prepositional Phrase), ApplP (Applicative Phrase). 
(3) $\quad \operatorname{VaNPNP}(\mathrm{V}$ IO DO)

A Maria deu ao João um livro.

the Mary gave to.the John a book

'Mary gave John a book'

(4) V dative clitic NP (V IOcl DO)

A Maria deu-lhe um livro.

the Mary gave cl3sg dative a book

'Mary gave him a book'

In EP clitic doubling is possible with a personal pronoun, mainly in an oral register; see (6) and (7) versus (5):

dative clitic doubling

(5) * Maria deu-lhe um livro ao João.

the Mary gave cl3sgdative a book to the John

(6) A Maria deu-lhe um livro a ele.

the Mary gave cl3sg dative a book to him

'Mary gave him a book'

(7) A Maria deu-lhe a ele um livro (e não a ela). the Mary gave cl3sg dative to him a book (and not to her)

'Mary gave him a book (and not to her)'

Many authors that have analysed the IO in EP and other Romance languages have noticed the special status of the IO: it behaves as a NP (marked by dative case) for effects of binding theory ${ }^{4}$ and it behaves as a PP for effects of predication ${ }^{5}$, where the presence of the preposition $a$ is mandatory (see, for Portuguese, Duarte (1987), Duarte (2003), Gonçalves (1990, 2002, 2004), Torres Morais (2006), Torres Morais \& Lima-Salles (2010)).

Another important aspect of ditransitive constructions is word order.

In the two sentences (2) and (3), what differs is the word order and the informational structure, being V DO IO the unmarked order and V IO DO the marked order. The proposal that the unmarked order in EP is V DO IO may be justified by several facts (cf. Costa (2009)): only (2), not (3), would be an adequate (redundant) answer to a wh question like (8):

[4] As Gonçalves (2002, pg. 336) writes, the preposition $a$ is "a case marker" of the only one argument IO with verbs like telefonar (to phone), and "a case assigner of an extra NP" with pedir, dar (to ask, to give) as the main Vs.

[5] Cf. Masullo (1992) for Spanish. 
(8) A quem é que a Maria deu o livro? to whom é que Mary gave the book 'To whom did Mary give the book?'

(3), with the order V IO DO, has a contrastive focus reading, being an adequate word order in a context like the one described in (9); therefore, a scrambling ${ }^{6}$ of the IO over the DO seems justified (see, for Spanish, Demonte (1995)). ${ }^{7}$

(9) A Maria deu ao João um livro, à Maria um CD. the Mary gave to.the John a book, to.the Mary a CD 'Mary gave John a book and she gave Mary a CD.'

Another fact in favor of the unmarked order V DO IO is the "O que aconteceu? / What happened questions?" (Costa 2009, pg. 95-6): if we have a question as in (10), the adequate answer is (2) and not (3):

O que aconteceu?

'What happened?'

It has been noticed (see, for instance, Duarte (2003, pg. 287, 290)) that, when the DO is a clause or a complex NP, as in (11-a), the order is typically V IO DO and not V DO IO, as in (11-b), which is marginal:

a. O João disse à Maria que vai sair. the John said to dative Mary that will leave 'John said to Mary that he will leave'

b. ?? O João disse que vai sair à Maria. the John said that will leave to dative $_{\text {Mary }}$

Even if we have a question with focus on the IO, as in (12), it is the order V IO DO that we expect, as in (11-a), and not the order V DO IO, as in (11-b), despite the fact that the IO is the information focus:

A quem disse a Maria que ia sair?

to whom said the Mary that was leave?

'To whom did Mary said that she was leaving?'

We may conclude that the order V IO DO is possible when one of the following factors is present: the IO is a contrastive focus; the DO is a complex, heavy constituent.

[6] The notion of "scrambling" is due to Ross (1967) and means the movement operation that is responsible for the change of the basic word order in a certain language by pragmatic and discursive reasons.

[7] An alternative to scrambling could be the proposal, inspired in Belletti (2004), according to which at the left periphery of the verbal domain (vP) there is place for discursive functional categories, like TopP, FocP. 
In order to verify if the order V IO DO is common in real texts, I have made a search on the corpus of CetemPúblico: it was possible to find many occurrences with this word order (see (13) and the Annex I at the end of this text):

par=ext1395495-pol-94a-2: O monarca jordano insistiu para que Israel não cedesse aos palestinianos o controlo da ponte Allenby sobre o rio Jordão, o que daria a Arafat a capacidade para controlar a migração de palestinianos e de militantes islâmicos - de Jericó para a Jordânia.

...which would give to Arafat the capacity for the control of the Palestinian migration -- and of Islamic militants -- from Jericho to Jordan.

It is visible that the V IO DO order is motivated by the complex nature of the DO (a capacidade para controlar a migração de palestinianos - e de militantes islâmicos de Jericó para a Jordânia).

In favor of V DO IO as the unmarked order, Costa (2009, pg. 95-6) says that idioms in EP are, in general, $\mathrm{V}$ DO IO, as in dar pérolas a porcos (give pearls to pigs) / *dar a porcos pérolas (give to pigs pearls - to cast pearls before swine). However, in proverbs and idioms the word order is also constrained by the clause nature or the complexity nature of both constituents; in fact, the two word orders can be found, as illustrated in the following examples with dar, 'to give'8 and many others that we can find in Portuguese books of proverbs (see Annex II):

"Dá Deus as nozes a quem não tem dentes." (V DO IO order)

God gives nuts to those who don't have teeth...

'What a waste!'

$$
\begin{aligned}
& \text { "Dar a Deus o que o Diabo não quis." (V IO DO order) } \\
& \text { to give to God what the Devil not wanted }
\end{aligned}
$$

What all these examples show is that two word order patterns are possible in Portuguese ditransitive constructions. It is true that in idioms and in some constructions with dar 'to give' as a light verb it is impossible to separate the $\mathrm{V}$ and the DO, as in dar uma lição a alguém 'to teach a lesson to someone' ((16-a) and (16-b)), showing that the link between the V and the DO cannot be broken; if this word order is changed, the literal meaning of to teach a lesson is expressed (16-b): ${ }^{9}$

(16) a. O António deu uma lição ao Pedro.

the Antony taught to.the Peter a lesson

'Antony taught a lesson to Peter'

[8] Proverbs in Machado (1996, pgs. 161-165).

[9] I thank Paula Carvalho for this observation; it is also important to remember that, in English, idioms are generally associated to the prepositional construction (with the order V NP PP) and not to the DOC (cf. Rapapport Hovav \& Levin (2008, pg. 131) and Ormazabal \& Romero (2010, pg. 209)). 
b. ?? O António deu ao Pedro uma lição.

the Antony taught a lesson to.the Peter

c. O António deu ao Pedro uma lição de português e à Maria uma de matemática.

the Antony taught to.the Peter a lesson of Portuguese and to.the Mary one of Math

'Antony taught Peter a lesson of Portuguese and taught Mary one of Math'

Summarising until now: in EP ditransitive constructions, $a$, as an IO introducer, is a dative marker and a preposition; the unmarked word order is V DO IO, although the order V IO DO is also possible as a marked order, with a contrastive focus on the IO and always that the complexity of the DO justifies its final position; in idioms, proverbs and in constructions with some ditransitive verbs as light verbs the order is preferentially V DO IO but the two orders are possible depending on the complex nature of the two constituents.

\section{[3] SOME APPROACHES OF DITRANSITIVE CONSTRUCTIONS IN GENERATIVE SYNTAX}

\section{[3.1] The main structures}

The structure of ditransitive constructions has been the subject of many discussions. In the beginning of Generative Syntax the structure (17) was proposed as a way to describe the selection of two internal arguments by ditransitive verbs: but (17) does not respect either binary branching or X-bar theory. ${ }^{10}$

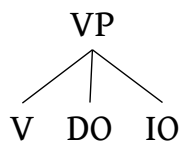

Also (17), where the DO and the IO occupy parallel positions, do not describe some data related to fronting, binding and scope; $(18)^{11}$ and $(19)^{12}$ were then proposed:

[10] The structures proposed in this paper will be very simplified; we will use syntactic functions in the representations as a way to describe the theme NP (the Direct Object, DO) and the beneficiary / goal / origin NP / PP (the Indirect Object, IO).

[11] (18) was used by Xavier (1989) for Portuguese. For English, (18) was proposed because of fronting and ellipsis, where the $\mathrm{V}$ forms a constituent with the DO, as in (i), although other fronting data are possible (see (ii), (iii) and (iv)): (i) ....and [give candy] he did to children on his birthday; (ii) John intended to give candy to children on his birthday; (iii) ....and [give candy to children on his birthday] he did; (iv) ...and [give candy to children] he did on his birthday (cf. Phillips (2003), Costa (2009, pg. 87-88)).

[12] (19) was proposed for English because of the superiority of the DO over the IO in sentences like (i) John gave nothing to any of the children on his birthday; in contrast with (ii) *John gave anything to none of the children on his birthday (cf. Phillips (2003), Costa (2009, pgs. 87-88)). 
(18)

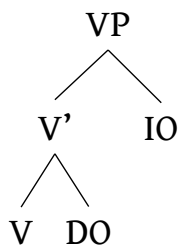

(19)

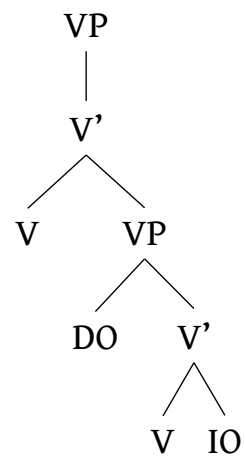

However, (18) and (19) are not sufficient, because the existence of the DOC in many languages and because of phenomena related to binding of pronouns and scope in certain occurrences favour a structure where the IO should be higher than the DO, as in $(20):{ }^{13}$

(20)

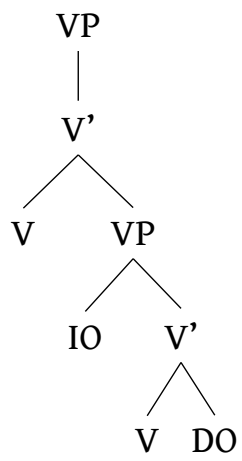

Supposing then that (19) and (20) are adequate, the immediate question is if (19) and (20) are base-generated structures or if they are derivationally related.

\section{[3.2] Different approaches of dative alternation}

In languages where there is alternation between the DOC and a prepositional construction, many solutions have been proposed in order to answer the above question, solutions that are connected to different approaches on the relation between lexical semantics and syntax. ${ }^{14}$

One approach is lexicalist / projectionist, based on the idea that lexical semantics encodes argument structure and determines the morphosyntactic realization of verb arguments (see Baker (1988), Rapapport Hovav \& Levin (2008));

[13] Cf. Barss \& Lasnik (1986) and Larson (1988, pg. 336-8), for English; see paragraph 5 for Portuguese.

[14] For an overview of different approaches see, among others, Ormazabal \& Romero (2010) and Oyharçabal (2010). 
The lexicalist approach is often - but not always - based on the idea of a single meaning for the two variants and proposes a derivational analysis in order to explain the alternation (Baker 1988; Larson 1988).

Oehrle (1976), Jackendoff (1990) and others noticed that, in English, the two constructions are not synonymous: the DOC would mean a change of possession, while the prepositional construction would the meaning of transfer of possession. Also, there would be an animacy requirement in the DOC that doesn't exist in the prepositional construction, which explains the ungrammaticality of (21-a):
a. *The editor sent Philadelphia the article.
b. The editor sent the article to Philadelphia.

Conversely, some occurrences of the DOC have no correspondent prepositional alternant, as in (22), where to give has an inanimate external argument and the sentence does not mean transfer of possession:
a. The war years gave Mailer a book.
b. *The war years gave a book to Mailer.

More recently,Rapapport Hovav \& Levin (2008) and Ormazabal \& Romero (2010) have shown that the dative alternation in English is not necessarily associated to differences in the meaning of the two variants; in particular, the differences found above are mainly due to differences in the lexical meaning of verbs: verbs like to give only have a caused possession meaning, while verbs like to send have both a caused motion and a caused possession meaning, what means that to send has a path dimension that is absent in to give.

Meanwhile, other proposals have been suggested.

One the most important is the neo-constructionist approach, where Syntax determines what is considered the argument structure of a lexical predicate. The neo-constructionist approach generally proposes two different structures for the DOC and for the prepositional construction, based on the idea of different meanings of the two variants, as referred above (Marantz 1993; Pesetsky 1995; Harley 2002; Anagnostopoulou 2003; Pylkkänen 2002; Cuervo 2003, 2010, among others).

(iii) There are also hybrid treatments like the one proposed by Ormazabal \& Romero (2010), where the framework based on event structure by Ramchand (2008) is combined with a derivational analysis.

\section{[3.3] Is the IO an applied argument?}

Crucial for the discussion of ditransitive construction is the status of the IO. Some approaches consider that there are argument and non argument IOs (Brito 2009, Gonçalves \& Raposo 2013, pgs. 1173-1181 for Portuguese; Pujalte $(2008,2009)$ for Spanish, among others). Therefore these approaches consider that there are some 
verbs that select a true second argument, the indirect object, the so called ditransitive verbs, like dar 'to give', prometer 'to promise' and that there are some non-argument datives. Other approaches assume that the IO is always an applied, extra or incorporated argument and that there are no ditransitive verbs (Marantz 1993, Cuervo 2003, 2010, among others).

Developing the idea that datives are not internal arguments of the verb, Marantz (1993, pg. 116) explicitly calls the DOC in English an applicative construction, which means that the dative is some sort of extra argument that is applied / incorporated to a verbal predicate. He proposes a structure where the applicative head is the light $v$, which takes an event as its argument, licensing the IO as its specifier and taking it as a participant in the event (23):

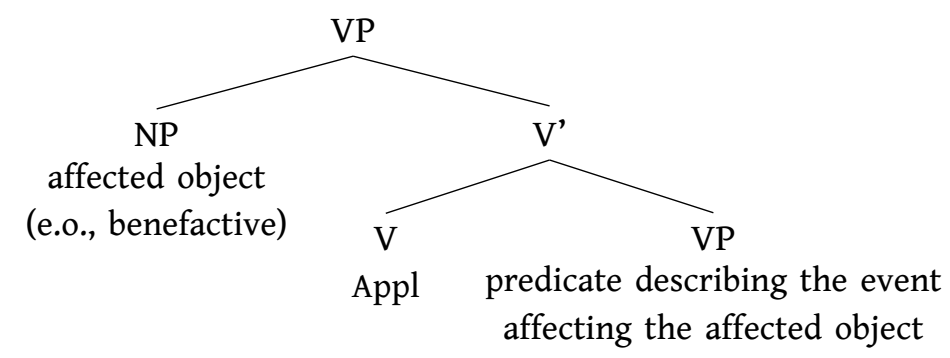

Developing Marantz's reflection, Pylkkänen (2002) proposes that English and Bantu languages are similar in the sense that the DOC is a type of applicative construction; but they are different in the sense that they project an Appl head in different positions. Bantu languages allow ergative verbs (like to run) or transitive verbs (like to give) to appear in an applicative construction, with a beneficiary / maleficiary argument and for this reason have high applicatives; in English, on the contrary, in order to have a DOC, it is necessary that the applied argument has some semantic relation with the verb (to give, to bake), so the applicative node is a low projection. ${ }^{15}$

At first sight, this sort of analysis would be rejected for Romance languages because they have no DOC, they have a special preposition to express the dative case and they have dative personal pronouns. However, Romance languages have been described by several authors as languages with dative alternation, with a construction similar to the DOC and with an applicative head. It is the case of Cuervo $(2003,2010)$ for Spanish, Torres Morais (2006) and Torres Morais \& LimaSalles (2010) for EP and Diaconescu \& Rivero (2005) for Romanian.

[15] For details see Pylkkänen (2002). 
[4] DATIVE ALTERNATION IN EP?

Clearly influenced by Demonte (1995) and Cuervo (2003) for Spanish and interested on the differences between Brazilian Portuguese (BP $)^{16}$ and EP, Torres Morais (2006) and Torres Morais \& Lima-Salles (2010) proposed an analysis according to which EP has dative alternation and justifies two base-generated constructions: it has a construction where a dative NP argument is projected in the specifier position of a low applicative head, as in (24) and another configuration, where there is a true preposition $a$, similar to para, that selects the IO as a complement, as in $(25):{ }^{17}$

O João enviou uma carta à Maria. the John sent a letter to.the Mary 'John sent Mary a letter.'

O João enviou uma carta à Maria / para a Maria / Lisboa / o Banco de Portugal.

the John sent a letter to.the Mary / Lisbon / the Bank of Portugal 'John sent a letter to Mary / Lisbon / the Bank of Portugal'

In (24) $\mathrm{a}$ is a dative case marker and the NP receives inherent case in the specifier of ApplP; as a low applicative, the head Appl receives the meaning of possession, which corresponds to the beneficiary interpretation, licensing the dative argument and relating it with the theme. ${ }^{18}$

This possibility differs from a true prepositional construction, possible in (25), where $a$ could be replaced by para as a way to mean the final goal of the event of sending the letter. In this second possibility, the possessive relation may also be built, but it is subordinated to the goal / transfer meaning of the preposition; a clitic is impossible here because "directional locatives are never realized as clitics" (Torres Morais \& Lima-Salles 2010, pg. 198).

The main questions that this analysis justifies are the following: are there any semantic differences that justify the two structures? Are there two prepositions $a$ in dative constructions? And is there a justification for an applicative head in this sort of dative construction?

[16] In Brazilian Portuguese the dominant preposition is para (to, for); and in certain geographical and social varieties even the DOC may be used (see Torres Morais \& Lima-Salles (2010). In Mozambique Portuguese the DOC is very common (see Gonçalves 1990, 2002, 2004); for a general presentation of the variation of the IO in non-European varieties of Portuguese see Brito (2008).

[17] For details see Torres Morais \& Lima-Salles (2010).

[18] The treatment is similar with the (O João enviou-lhe uma carta, John sent him a letter) with subsequent movements that explain the final word order. 
Notice that the notion of possession transfer is always stronger with Vs like dar, 'to give', emprestar, 'to loan', alugar, 'to rent', vender, 'to sell' (cf. Ormazabal \& Romero 2010, pg. 208-9, from whom we adapt some of the examples); in fact, (26) is odd, because the constrastive clause denies the implication of the main clause:

$$
\begin{aligned}
& \text { \# A minha tia deu / emprestou algum dinheiro ao irmão, mas ele nunca o } \\
& \text { recebeu. } \\
& \text { the my aunt gave / lent some money to the brother, but he never it got } \\
& \text { 'My aunt gave / lent some money to her brother, but he never got it.' }
\end{aligned}
$$

On the contrary, with verbs like prometer, 'to promise', oferecer, 'to offer', enviar, 'to send', ensinar, 'to teach', lançar, 'to throw', the situation is different and there is the possibility of "failure of successful transfer" (Ormazabal \& Romero 2010, pg. 209):

(27) A Câmara ofereceu ajuda às vítimas, mas elas recusaram a oferta. the municipality offered help to.the victims, but they refused the offer 'The municipality offered help to the victims, but they refused its offer'

As Portuguese allows different variants of the ditransitive construction, mainly due to the presence of clitics, clitic doubling and also word order, it is important to verify if the meaning of transfer of possession is similar in all the variants of the construction with this second class of predicates. Let us look for all the possible variants with enviar (28)-(32):

(28) O José enviou uma carta à Maria (mas ela não a recebeu). the Joseph sent a letter to.the Mary (but she not it received) 'Joseph sent a letter to Mary (but she didn't receive it)'

(29) O José enviou à Maria uma carta (mas ela não a recebeu). the Joseph sent to.the Mary a letter (but she not it received) 'Joseph sent Mary a letter but she didn't receive it'

(30) O José enviou-lhe uma carta (mas ela não a recebeu). the Joseph sent her a letter (but she not it received) 'Joseph sent her a letter but she didn't receive it'

(31) O José enviou-lhe uma carta a ela (mas ela não a recebeu). the Joseph sent herdative a letter to her (but she not it received) 'Joseph sent her a letter but she didn't receive it'

(32) O José enviou-lhe a ela uma carta (mas ela não a recebeu). the Joseph sent herdative to her a letter (but she not it received) 'Joseph sent her a letter but she didn't receive it' 
We see from (28)-(32) that the notion of transfer of possession expressed by enviar, to send, may always be (pragmatically) cancelled in all the versions of the ditransitive construction. All these sentences are therefore semantically equivalent, the clitic lhe and the sequence $a N P$ in both positions being similar in the expression of the beneficiary / goal. We may then conclude that $a$ in all the examples is the same dative case marker preposition, the same type of preposition. So, two different structures for ditransitive verbs on the basis of a possible non-synonymy between the two different variants of the ditransitive construction seem not justified, contrary to which is suggested by Torres Morais \& Lima-Salles (2010). Moreover, a e para may co-occur with different meanings, $a$ meaning the goal / origin and para meaning the beneficiary (Brito 2009; Gonçalves \& Raposo 2013, 1177):

A Maria comprou um livro à vendedora para a filha.

The Mary bought a book to the seller (origin) for the daughter (beneficiary)

'Mary bought the seller a book for her daughter.'

Also, if the classical notion of ditransitive verbs is still in use, an applicative head as a low verbal category seem also unjustified for EP: the idea is that some verbs like dar 'to give', select two true internal arguments. ${ }^{19}$

We have seen before that ditransitive constructions justify two syntactic structures; but these two syntactic structures should not be based either on different meanings or on the different nature of the preposition. In the next section we will investigate some fronting, ellipsis, binding and scope phenomena and we will see that two base-generated ditransitive constructions may be justified in EP, a proposal already made for Portuguese by Costa (2009).

[5] ARgument ditransitives in European portuguese: TWo baseGENERATED STRUCTURES

Fronting and ellipsis illustrated in (34-a) (examples from Costa (2009)), provide evidence in favor of an analysis where the $\mathrm{V}$ and the DO form a constituent and therefore this example may justify a structure like (20): ${ }^{20}$

(34) O Pedro queria dar os livros ao Rui ontem. the Pedro wanted give the books to.the Rui yesterday

[19] Miguel et al. (2011), analysing benefactive non-argument datives (a mãe preparou uma refeição à filha / a mãe preparou-lhe uma refeição, mother prepared a meal to her daughter / mother prepared her a meal) and possessives datives (doem as costas ao João / doem-lhe as costas, John's back hurt / his back hurt) propose that they are merged, along with DP-Themes, under the internal argument, broadly interpreted as Possessive $D P$ and exhibiting a predicative structure; according to this analysis, no applicative head is justified.

[20] Costa uses these data in favor of the structure (18). 
a. e [dar os livros] ele deu ao Rui ontem.

and give the books he gave to.the Rui yesterday

b. e [dar os livros ao Rui] ele deu ontem.

and give the books to.the Rui he gave yesterday

'Pedro wanted to give the books to Rui yesterday and give the books to Rui he did'. ${ }^{21}$

Barss \& Lasnik (1986) and Larson (1988) noticed, for English, that there are some asymmetries on binding that question not only a tripartite configuration of ditransitive constructions (as in (11)) but also a bipartite configuration where the IO is lower than the DO. It is why Larson proposes a derivational analysis of the DOC in English, where the raised IO (the beneficiary/goal) would c-command the DO (the theme) after movement.

Let us see the distribution of anaphors in ditransitive constructions in EP; the examples are inspired by Demonte' 1995 study for Spanish (Costa 2009; Brito 2010):
a. ?? O tratamento psicoanalítico devolveu [a estima de si mesma] à Maria.
'The psychoanalytic therapy gave back her self-esteem to Mary'
b. O tratamento psicoanalítico devolveu à Maria [a estima de si mesma]. 'The psychoanalytic therapy gave back to Mary her self-esteem'

The two variants are possible, similarly to what has been proposed for other Romance Languages (Giorgi \& Longobardi 1991, pg. 42 for Italian), but the sentence with the low reflexive expression (35-b) is slightly better than the sentence where the reflexive expression is higher than its antecedent (35-a).

Let us see now the same phenomenon with clitic doubling:

a. ?? O tratamento psicoanalítico devolveu-lhe [a estima de si mesma] a ela.

the therapy psychoanalytic gave back her dative the self-esteem to her 'The psychoanalytic therapy gave back her self-esteem'

[21] According to Adger (2003, pgs. 124-125) in English it is not possible to make VP preposing with the V and the DO (i) *Benjamin said he would give the cloak to Lee and [give the cloak] he did to Lee. For him, ellipsis seems to give the same results: (ii) Who gave the cloak to Lee? ${ }^{*}$ Benjamin (did) to Lee. As for coordination, although we can have (iii) Benjamin [gave the cloak] and [sent the book] to Lee, this is possible "only" with a substantial pause after cloak as well as odd intonation on the PP to Lee, suggesting that we have a case of deletion: (iv) Benjamin [gave the cloak 0] and [sent the book to Lee]. Adger considers that the behaviour of reflexives favors a binary branching analysis for ditransitive constructions in the prepositional construction under a shell structure with vP, although he considers that "there is weak evidence from constituency" in favour of this treatment. Notice that Adger judgements for English are different from the ones by Phillips (2003), who admits VP preposing (see footnote 11). 
b. O tratamento psicoanalítico devolveu-lhe a ela [a estima de si mesma]. the therapy psychoanalytic gave back her dative to her the self-esteem 'The psychoanalytic therapy gave back her self-esteem'

Due to the presence of clitic doubling, there is here a contrastive focus and a marked interpretation; nevertheless, the sentence (36-b) with the low reflexive expression is slightly better than the sentence where the reflexive expression is higher than its antecedent (36-a).

Let us see how EP behaves as regards other phenomena of binding of pronouns.

In EP null possessives with a bound reading are always better than the ones with the possessive seu, sua; moreover seu, sua is frequently interpreted as the second person, related to você, two reasons that interfere with these phenomena (Brito 2001). Nevertheless, the data favour a higher position of the antecedent over the expression that contains the possessive, no matter the antecedent is the DO or the IO:
a. ?? A professora entregou [o $(\mathrm{seu})_{\mathrm{i}}$ desenho] a cada criança $\mathrm{a}_{\mathrm{i}}$ the teacher gave the his drawing to each child 'The teacher gave its drawing to each child'
b. A professora entregou [cada desenho $\left.\mathrm{i}_{\mathrm{i}}\right]_{\text {ao }}(\mathrm{seu})_{\mathrm{i}}$ autor. the teacher gave each drawing to.the its author 'The teacher gave each drawing to its author'
c. ?? A professora entregou ao $(\mathrm{seu})_{\mathrm{i}}$ autor [cada desenho ${ }_{\mathrm{i}}$ ]. the teacher gave to.the its author each drawing 'The teacher gave to its author each drawing.'
d. A professora entregou a cada criança $a_{i}\left[o(s e u)_{i}\right.$ desenho]. the teacher gave to each child to.the his drawing 'The teacher gave to each child its drawing'

These phenomena suggest a shell structure and the idea that the highest argument is base-generated; the same proposal is reinforced by other examples where binding and scope of quantifiers are involved (cf. again Costa 2009): ${ }^{22}$

(38) a. * Apresentei a Maria à filha da Maria introduced the Mary to.the daughter of the Mary

b. Apresentei à filha da Maria ${ }_{i}$ a Maria ${ }_{i}$. introduced to.the daughter of.the Mary the Mary 'I introduced Mary to Mary's daughter'

[22] Bruening (2001), for English, also proposes that there two available structures for ditransitives and that there is no scrambling in order to explain the V IO OD order. 
c. Apresentei uma mulher a todos os homens

introduced a woman to all the men

'I introduced a woman to all the men.'

(preferred interpretation $\exists>\forall$ )

d. Apresentei a todos os homens uma mulher.

introduced to all the men a woman

'I introduced to all the men a woman'

(preferred interpretation $\forall>\exists$ )

Costa (2009)[pgs. 95-96] defends that these phenomena support a structure where the antecedent / the highest argument is base-generated, no matter it is the DO or the IO.

What all these data suggest is that EP has two base-generated ditransitive constructions, like (19) and (20), justified by word order data already presented above, fronting, binding and scope phenomena, and not on different meanings of each variant or the existence of two different values of $a^{23}$. Through both structures, the ditransitive verb builds its argument structure, in one discharging first the theme, in another discharging first the goal / beneficiary.

\section{[6] SUMMARY AND CONCLUSIONS}

In this paper EP ditransitive constructions with dar 'to give' and enviar 'to send', were studied in some of their syntactic dimensions: EP has dative pronouns, a special preposition $a$ and exhibits two word patterns, V DO IO and V IO DO. We have seen that the order V IO DO is due to two reasons: contrastive focus on the IO or the complexity of the DO. This conclusion was reinforced by the analysis of many utterances in the corpus of CetemPúblico. Nevertheless there is a strong link between the $\mathrm{V}$ and the $\mathrm{DO}$ in certain constructions with dar as a light verb that cannot be broken.

I revised some of the literature on IO / datives and on the DOC. Specifically, I commented Torres Morais \& Lima-Salles (2010) analysis, according to which EP has dative alternation, in the sense that in one of the structures $a$ is a dative case marker and in another structure is a low true preposition, similar to para. According to these authors the two constructions are not absolutely synonymous.

On the contrary, I proposed that $a$ is the same dative marker in both positions;

[23] As we saw above, there have been different proposals in the literature to describe the two variants. Costa (2009) adopts Phillips (2003) framework, according to which there is an incremental structure building, from left-to-right but preserving c-command and allowing to build two base-generated structures. Brito (2014) adopts a treatment inspired in Alexiadou et al. (2011) framework, according to which a (verb) root is dominated by different functional categories which build syntactic structure; but, contrary to Marantz, Pylkännen, Cuervo, Torres Morais \& Lima Salles, which use the Appl head in order to explain the incorporation of the IO, the author still makes a distinction between argument datives and nonargument datives and therefore no Appl head is proposed. For the details of the analysis see Brito (2014). 
in EP the sentences with the and $a \mathrm{NP}$ are synonymous and no semantic difference is found. So, neither the nature of $a$ or semantic differences justify the proposal that EP has dative alternation. An applicative head seems then unnecessary, unless, perhaps, for extra / applied / non-argument datives, that were not analysed in this text. The crucial fact that may distinguish ditransitive constructions is the lexical nature of the verb: some of them have a path dimension, others not. But a detailed analysis of the so called ditransitive verbs was beyond the goal of this paper.

Fronting, ellipsis, binding and scope justify the proposal of two base-generated structures, as already shown by Costa (2009) for EP. In one syntactic structure the $\mathrm{DO}$ is projected as the complement of the $\mathrm{V}$ and the IO occupies the position of specifier of VP; in another structure the DO occupies the position of specifier of $\mathrm{VP}$ and the IO is the complement of a low V projection.

This is possible because we used a dynamic notion of lexicon, in the sense that there is more than one syntactic structure, more than one construction that is consistent with the encyclopedic meaning of ditransitive verbs like dar, to give, and enviar, to send, etc. The proposal was that there are two possible ways of building the argument structure of ditransitive verbs in syntax; these verbs discharge either first the theme or first the beneficiary.

In conclusion, EP has dative alternation but not in the same sense that English has dative alternation.

\section{ACKNOWLEDGMENTS}

I thank Paula Carvalho for helping me to pick up the examples in the corpus of CetemPúblico. As a member of Centro de Linguística da Universidade do Porto (CLUP), this research was supported by FEDER / POCTI U0022/2003.

\section{ANNEX I}

From CetemPúblico, relevant occurrences in bold.

par=ext989232-pol-96a-2: «Temos de dar a Samper uma saída», disse o senador conservador Eduardo Pizano, citado pela Reuter, como quem antevê o caos depois da tempestade.

par=ext127620-nd-91a-1: Não é por acaso que agora, no seu primeiro projecto pessoal, deu a Price o papel de Inventor.

par=ext578006-des-95a-1: «Duas vitórias sucessivas dão a um jogador muita confiança», confessou Muster após a final, em que, mais uma vez, demonstrou as suas qualidades físicas.

par=ext472583-soc-95b-2: É possível sustentar a tese de que essa é uma maneira oblíqua e astuta de o ferir, inclusive porque torna mais difícil o divórcio e dá a Diana melhores condições se, apesar de tudo, este vier a acontecer.

par=ext694500-pol-91b-3: Os raptores deram a Bona um prazo de 48 horas para fornecer informações sobre o estado de saúde dos irmãos Hamadi, dois xiitas libaneses detidos na Alemanha sob acusações de terrorismo. par=ext711722-soc-91b-2: Como a versão tinta, mas «sem gralhas», como ironiza Augusto Deodato, a agenda apresenta uma selecção que visa dar a quem «resida ou venha a Lisboa a oportunidade de gerir melhor os interesses nesta cidade». 
par=ext796563-soc-96b-1: É por estas e por outras, concluiu Lobo Fernandes, que o «prestigiado 'Guia Verde’ da Michelin dá a Braga a nota mais baixa (uma estrela) na classificação das cidades que apresenta no seu roteiro turístico. par=ext1344780-nd-91a-1: Para Setembro, deverá ter obtido sinais de reactivação que dêem a Carlos Menem uma vitória nas eleições legislativas, o que para muitos peronistas é uma missão impossível. par=ext856353-clt-96b-2: O objectivo é dar a professores, alunos e outros funcionários a possibilidade de consultarem um árbitro para resolverem os seus diferendos pessoais ou institucionais.

par=ext660500-nd-98b-2: A evolução do escândalo Monica Lewinsky deu a Hyde uma enorme notoriedade nacional - e enquanto o caso não for fechado de vez o senador de pensamento conservador (que há 30 anos teve um caso extraconjugal) vai continuar a estar sob os holofotes.

par=ext121571-soc-94b-1: "O Governo português só deu a Bruxelas a informação que lhes convinha, não enviando sequer os pareceres produzidos no âmbito da consulta pública feita sobre o Estudo de Impacte Ambiental (...)».

par=ext755655-clt-96b-3: Na sequência final, a suprema crueldade de Wilder dava a Cecil B. de Mille a oportunidade de domar, pela última vez, a beleza da sua ave do paraíso enlouquecida.

par=ext320712-pol-94a-1: "Onde é que ia arranjar dinheiro para dar a esses homens a comida, as roupas e o sabão de que necessitariam?", perguntou indignado o general Niha, primeiro secretário da Frelimo na província de Nampula.

par=ext582831-des-92a-2: Uma sondagem Público-Norma realizada no domingo no Estádio da Luz, por ocasião do jogo Benfica-FC Porto, deu a Jorge de Brito a maioria absoluta para as eleições de 24 de Abril.

par=ext585073-pol-98a-4: Mas uma sondagem divulgada no fim-de-semana dá a Cardoso uma confortável margem: 40 por cento, contra 35 por cento para todos os seus rivais somados.

par=ext677371-pol-92b-2: O Congresso terá que assumir a responsabilidade de dar a Itamar a possibilidade de organizar o Estado, que foi desorganizado nos últimos seis anos. par=ext1371639-pol-93a-1: Dia importante, este 27 de Abril de 1993 - ainda mais que aquele, no Verão de há três anos, em que Gorbatchov deu a Bush luz verde para a coligação anti-Iraque.

par=ext221520-clt-94b-2: Lestat, quando viu o que Louis tinha feito, deu a Claudia um pouco do seu sangue a beber, transformando-a também em vampiro, para a oferecer a Louis .

par=ext1405400-nd-94b-1: Muñoz Molina manifesta uma categórica afinidade com aqueles que dão a Lisboa e a Portugal a forma e conteúdo da nossa peculiar identidade.

par=ext1180148-pol-97b-2: A Assembleia da República recusou dar a Pacheco Pereira a «prerrogativa» de depor apenas por escrito num processo por abuso de liberdade de imprensa que lhe foi movido pela actual directora do vespertino «A Capital», Helena Sanches Osório.

par=ext269933-soc-91a-1: João Paulo II não deixou de dar a este debate o seu contributo.

par=ext403476-nd-93b-1: O Estado Novo, dentro dos limites consentidos pelas suas opções estratégicas, deu a Pacheco meios quase ilimitados de concretizar o seu voluntarismo modernizador.

par=ext732008-pol-93a-1: A campanha eleitoral começou a dar os primeiros passos logo no sábado, após a dissolução oficial do Parlamento, que apanhou os desprevenidos os deputados que não esperavam que a moção de censura contra o Governo de Hanna Suchocka fosse aprovada, dando a Walesa o pretexto que ele esperava para dissolver o Parlamento.

par=ext670069-pol-93b-2: Dar a cada cubano a possibilidade de possuir, legalmente, a moeda do inimigo, o dólar, será assim quebrar um dogma.

\section{A N NEX II}

Some proverbs with dar 'to give', from Machado (1996, pgs. 161-165) and Parente (2005, pg. 184).

(i) V DO IO order:

Dá Deus as nozes a quem não tem dentes.

Dá Deus toucinho a quem não tem espeto.

Dá honra a quem não a tem.

Dá Nosso Senhor campos a quem não aproveita os toucinhos. 
Dá ofício ao vilão, conhecê-lo-ão.

Dar o seu a seu dono.

Dar pão a quem não tem pão é esmola de carvão.

(ii) V IO DO order:

Dar a teu filho bom nome e bom ofício.

Dá ao gato o que o rato tem de levar / dar ao gato o que há levar o rato.

Dai a cada um o que é seu.

Dar a Deus o que é de Deus e a César o que é de César.

Dar a Deus o que o Diabo não quis.

\section{REFERENCES}

Adger, David. 2003. Core syntax: A minimalist approach Core linguistics. Oxford University Press.

Alexiadou, Artemis, Gianina Iordăchioaia \& Florian Schäfer. 2011. Scaling the variation in romance and germanic nominalizations. In Petra Sleeman \& Harry Perridon (eds.), The noun phrase in Romance and Germanic: Structure, variation, and change Linguistik Aktuell, 25-40. John Benjamins Publishing Company.

Anagnostopoulou, Elena. 2003. The syntax of ditransitives: Evidence from clitics Studies in generative grammar. Mouton de Gruyter.

Baker, Mark Cleland. 1988. Incorporation. a theory of grammatical function changing. The University of Chicago Press.

Barss, Andrew \& Howard Lasnik. 1986. A Note on Anaphora and Double Objects. Linguistic Inquiry 17. 347-354.

Belletti, Adriana. 2004. Aspects of the low IP area. In Luigi Rizzi (ed.), The Structure of CP and IP: The Cartography of Syntactic Structures, vol. 2 Oxford Studies in Comparative Syntax, Oxford University Press.

Brito, Ana Maria. 2001. Presença/ausência de artigo antes de possessivo no Português do Brasil. In Actas do xvi encontro da associação portuguesa de linguística, 551-575. APL/Colibri.

Brito, Ana Maria. 2008. Grammar variation in the expression of verb arguments: the case of the Portuguese Indirect Object. Phrasis 2008. 31-58.

Brito, Ana Maria. 2009. Construções de objecto indirecto preposicionais e não preposicionais: uma abordagem generativo-constructivista. In A. Fiéis \& A. Coutinho (eds.), Textos Seleccionados do XXIV Encontro da Associação Portuguesa de Linguística, 141-159. Colibri. 
Brito, Ana Maria. 2010. Do European Portuguese and Spanish have the double object construction? In Encuentrogg. $v$ encuentro de gramática generativa (2009), 81-114.

Brito, Ana Maria. 2014. As construções ditransitivas revisitadas. alternância dativa em Português Europeu? In António Moreno, Fátima Silva, Isabel Falé, Isabel Pereira \& João Veloso (eds.), Textos selecionados: Xxix encontro nacional da associação portuguesa de linguística, 103-119.

Bruening, Benjamin. 2001. QR obeys superiority: frozen scope and ACD. Linguistic Inquiry 32(2). 233-273.

Costa, João. 2009. A focus-binding conspiracy. Left-to-right merge, scrambling and binary structure in European Portuguese. In Jeroen van Craenenbroeck (ed.), Alternatives to cartography, 87-108. De Gruyter Mouton.

Cuervo, Maria Cristina. 2003. Datives at Large: Massachusetts Institute of Technology $\mathrm{PhD}$ dissertation.

Cuervo, Maria Cristina. 2010. Against ditransitivity. Probus 22.151-180.

Demonte, Violeta. 1995. Dative alternation in Spanish. Probus 7. 5-30.

Diaconescu, Constanţa Rodica \& Maria Luisa Rivero. 2005. An applicative analysis of double constructions in Romanian. In Actes du Congrès annuel de l'Association Canadienne de Linguistique, 1-11.

Duarte, Inês. 1987. A construção de topicalização na gramática do português: regência, ligação e condições sobre movimento: Universidade de Lisboa PhD dissertation.

Duarte, Inês. 2003. Relações gramaticais, esquemas relacionais e ordem de palavras. In M. Helena Mira Mateus, Inês Duarte \& Isabel Hub Faria (eds.), Gramática da língua portuguesa, 275-321. Caminho 5th edn.

Giorgi, Alessandra \& Giuseppe Longobardi. 1991. The Syntax of Noun Phrases: Configuration, Parameters and Empty Categories. Cambridge University Press.

Gonçalves, Anabela \& Eduardo Paiva Raposo. 2013. Verbo e sintagma verbal. In Eduardo Paiva Raposo, Maria Fernanda Bacelar do Nascimento, Antónia Coelho da Mota, Luísa Segura \& Amália Mendes (eds.), Gramática do português, vol. 2, 1155-1218. Fundação Calouste Gulbenkian.

Gonçalves, Perpétua. 1990. A Construção de uma Gramática do Português em Moçambique: Aspectos da Estrutura Argumental dos Verbos: Universidade de Lisboa PhD dissertation. 
Gonçalves, Perpétua. 2002. The role of ambiguity in second language change: the case of Mozambique African Portuguese. Second Language Research 18(4). 325347.

Gonçalves, Perpétua. 2004. Towards a unified vision of classes of language acquisition and change: Arguments from the genesis of Mozambique African Portuguese. Journal of Pidgins and Creole Languages 19(2). 225-259.

Harley, Heidi. 2002. Possession and the double object construction. Yearbook of Linguistic Variation 2. 29-68.

Jackendoff, Ray. 1990. On Larson's treatment of the double object construction. Linguistic Inquiry 21. 427-456.

Kayne, Richard S. 1984. Connectedness and binary branching Studies in generative grammar. Foris Publications.

Larson, Richard. 1988. On the double object construction. Linguistic Inquiry 19. 335-392.

Machado, João Pedro. 1996. O grande livro dos provérbios. Notícias Editorial.

Marantz, Alex. 1993. Implications of Asymmetries in Double Object Constructions. In Sam A. Mchombo (ed.), Theoretical aspects of Bantu Grammar, vol. 1, 113-150. CSLI Publications.

Masullo, Pascual José. 1992. Incorporation and case theory in Spanish: a cross-linguistic perspective: University of Washington dissertation.

Miguel, Matilde, Anabela Gonçalves \& Inês Duarte. 2011. Dativos não argumentais em português. In Textos seleccionados, xxvi encontro da associação portuguesa de linguística, 388-400. APL.

Oehrle, Richard. 1976. The grammatical status of the English dative alternation: Massachusetts Institute of Technology PhD dissertation.

Ormazabal, Javier \& Juan Romero. 2010. The derivation of Dative Alternation. In Maia Duguine, Susana Huidobro \& Nerea Madariaga (eds.), Argument Structure and Syntactic Relations, 203-232. John Benjamins.

Oyharçabal, Beñat. 2010. Basque ditransitives. In Maia Duguine, Susana Huidobro \& Nerea Madariaga (eds.), Argument Structure and Syntactic Relations, 233-260. John Benjamins.

Parente, Salvador. 2005. O livro dos provérbios. Âncora Editora. 
Pesetsky, David. 1995. Zero Syntax: Experiencers and Cascades. The MIT Press.

Phillips, Colin. 2003. Linear order and constituency. Linguistic Inquiry 34(1). 37-90.

Pujalte, Mercedes. 2008. Sobre frases aplicativas y complementos dativos en el español del Rio de Plata. Cuadernos de Lingüistica 15. 139-156.

Pujalte, Mercedes. 2009. Condiciones sobre la Introducción de argumentos. El caso de la alternancia dativa en Español. Universidad Nacional del Comahue, Escola Superior de Idiomas MSc thesis.

Pylkkänen, Liina. 2002. Introducing Arguments: Massachusetts Institute of Technology $\mathrm{PhD}$ dissertation.

Ramchand, Gillian. 2008. Verb Meaning and the Lexicon: a first phase syntax. Cambridge University Press.

Rapapport Hovav, Malka \& Beth Levin. 2008. The English dative alternation: the case for verb sensitivity. Journal of Linguistics 44. 129-167.

Ross, John Robert. 1967. Constraints on variables in Syntax: Massachusetts Institute of Technology dissertation.

Torres Morais, Maria Aparecida. 2006. Um cenário para o núcleo aplicativo no português europeu. ABRALIN 5. 239-266.

Torres Morais, Maria Aparecida \& Heloísa Lima-Salles. 2010. Parametric change in the grammatical encoding of indirect objects in Brazilian Portuguese. Probus 22. 181-209.

Vilela, Mário. 1992. Gramática de Valências. Teoria e aplicação. Almedina.

Xavier, Maria Francisca. 1989. Argumentos Preposicionados em Construções Verbais. Um estudo contrastivo das preposições $a$, de e to, from: Universidade Nova de Lisboa PhD dissertation.

CONTACTS

Ana Maria Brito

Faculdade de Letras da Universidade do Porto

ambarrosbrito@gmail.com 